\title{
Putting the Demos Back Into the Concept of Democratic Quality
}

\section{Citation}

Mayne, Quinton and Brigitte Geissel. 2016. Putting the demos back into the concept of democratic quality. International Political Science Review.Forthcoming.

\section{Permanent link}

http://nrs.harvard.edu/urn-3:HUL.InstRepos:25286593

\section{Terms of Use}

This article was downloaded from Harvard University's DASH repository, and is made available under the terms and conditions applicable to Open Access Policy Articles, as set forth at http:// nrs.harvard.edu/urn-3:HUL.InstRepos:dash.current.terms-of-use\#OAP

\section{Share Your Story}

The Harvard community has made this article openly available.

Please share how this access benefits you. Submit a story.

\section{Accessibility}




\title{
Putting the demos back into the concept of democratic quality ${ }^{1}$
}

\section{Quinton Mayne}

Harvard Kennedy School

Brigitte Geissel

Goethe University Frankfurt

Forthcoming in International Political Science Review.

\begin{abstract}
In this paper we argue that the concept of democratic quality consists of two necessary, but independently insufficient, components. The first is an opportunity-structure component, which includes the institutional and structural opportunities that allow for democratic rule. The second is a citizen component, which refers to the ways in which citizens can and do breathe life into existing institutional opportunities for democratic rule. Based on work from political theory we show how different ontologies or models of democracy place different demands on citizens as much as they do on institutions. We demonstrate the need for quality-of-democracy research to engage with work in political behavior and political psychology, from which it has traditionally been disconnected. In doing so, we provide a parsimonious analytic framework for a theory-
\end{abstract}

${ }^{1}$ We thank the editors and reviewers of the IPSR for their suggestions and comments as well as Sibylle Hardmeier. The paper has benefited greatly from the feedback of Matt Baum, Archon Fung, Sergiu Gherghina, Imke Harbers, Jane Mansbridge, Pippa Norris, Jonathan Rinne, Ryan Sheely, and Graham Smith. We are also grateful for lively conversations with colleagues at a number of professional gatherings: the 2012 Democracy Seminar at the Ash Center for Democratic Governance and Innovation at Harvard Kennedy School, a panel at the 2013 ECPR General Conference in Bordeaux, and a "Measuring Democracy" workshop held in 2013 in Frankfurt. 
driven selection of indicators related to three key citizen dispositions: namely, democratic commitments, political capacities, and political participation. The paper ends with a brief discussion of important implications of our argument for the future study of democratic quality. 
There is no shortage of indices that aim to measure variations in democratic quality. Yet despite the multidimensionality and diversity of the indicators used in these existing indices, the concept of democratic quality continues to be viewed predominantly through a single (albeit wide-angle) lens focused on the institutional and structural opportunities for democratic rule. To borrow the words of the political philosopher Will Kymlicka (2002: 285), the current focus of quality-ofdemocracy indices suggests that 'democracy [can] function effectively even in the absence of an especially virtuous citizenry.' In the pages that follow we make a case against this conception of democratic quality. We argue instead that democratic quality consists of two necessary, but independently insufficient, components. The first is an opportunity-structure component, which includes the institutional and structural opportunities that allow for democratic rule. The second is a citizen component, which refers to the ways in which citizens can and do breathe life into existing institutional opportunities for democratic rule. For the sake of simplicity we call this an ‘institutions-in-reality' understanding of democratic quality.

The lack of attention paid to citizens in current quality-of-democracy work stands apart from a number of long-standing bodies of research within political science, all of which place citizens at the center of the notion of democratic performance. This includes various strands of political theory as well as the fields of political behavior and political psychology. Our aim with this paper is to show how quality-of-democracy research can be enhanced by better engaging with these research traditions. In making a case for the systematic inclusion of citizens in the conceptualization of democratic quality, we are not therefore introducing a new view of democracy. The idea that citizens are conceptually constitutive of democratic quality is a standard view among political scientists of various ilks. Our hope is that as the field of qualityof-democracy research develops in future years, the current preoccupation with institutions will 
be supplemented with an equally robust focus on citizens. In short, when it comes to measuring democratic quality, institutions matter, but so too do citizens.

Including citizens in a full and systematic manner in future comparative quality-of-democracy research is not just important from the point of view of concept formation, it is also important because of the significant changes it will produce in current scores and rankings of democracies. To illustrate this point, take the following types of cross-national variation in citizen attitudes and behavior. ${ }^{1}$ Whereas only two thirds of Portuguese citizens believe it is important for their country to be governed democratically, nine out of 10 Swedes hold the same opinion. Just over a fifth of citizens in the Czech Republic say they are very or fairly interested in politics, while in the Netherlands this figure is three times as large; and in the United States, roughly two-thirds of citizens report following what is going on in government some or most of the time. When posed three factual questions related to national politics, more than 50 percent of Danes answered all three correctly, whereas the same was true of only 10 percent of Lithuanians. Besides differences in electoral turnout, sizeable variations exist across countries in other forms of democratic activism. In Iceland, one in four citizens report having contacted a public official in the past twelve months; in Poland, the figure is one in fourteen. 17 percent of people in Chile report having signed a petition in the past year; in New Zealand the number is four times as high. Yet, despite these large differences in how citizens think and act, all of these countries receive the exact same score from Freedom House, a widely used index of democratic quality. The same is true of India and Peru. Yet, using measures of tolerance, identified as a key feature of a wellfunctioning democracy by scholars of political theory and political behavior, we observe large differences across these two countries. In Peru, a little over 10 percent of citizens say they would 
not like to have neighbors of a different religion; the same is true of just over 50 percent of Indians.

The above examples are illustrations of the types of citizen dispositions that might be included in future quality-of-democracy indices. However, as we show in this paper, which citizen-related indicators are to be included depends crucially on the model or ontology of democracy driving the evaluative exercise. All in all, including a full, systematic, and appropriate range of citizen-related indicators in future quality-of-democracy research will allow for greater differentiation in quality between democracies that will certainly have an impact on existing rankings and scores.

In addition to producing a measure with greater face and construct validity, fully incorporating citizen-related indicators is important for a second reason: it offers the possibility of putting the concept of democratic quality to better analytic use. As the field of quality-ofdemocracy research develops in the coming years, our analytic gaze will broaden out from focusing mainly on trying to measure quality of democracy to trying to explain its causes and consequences. Including citizen-related indicators will, we hope, offer particular analytic benefits for the latter area of research that focuses on democratic quality as an explanatory variable. By conceiving of democratic quality not simply with reference to how a set of institutions function but also in terms of how citizens bring these institutions to life, future research should be better equipped to identify the effects of democratic quality on a range of substantively important phenomena, including democratic stability and policy responsiveness.

Given the conceptual impetus of this special issue, it important to note that our aim here is not to operationalize the citizen component of democratic quality but rather to make the case for the inclusion of citizens and, importantly, to provide a parsimonious analytic framework for future 
cross-national empirical research. In developing our framework we deliberately avoid a definitive or prescriptive account of the 'good democratic citizen.' We argue and show instead that different models of democracy emphasize different types and levels of three key categories of citizen dispositions: namely, democratic commitments, political capacities, and political participation.

It is also important to explain the place of causality in our conceptualization of democratic quality. In democratization studies, there are longstanding discussions of the causal import of mass citizen dispositions in producing democratic transitions and consolidation (see, e.g., Rustow, 1970; Bermeo, 2003; Inglehart and Welzel, 2005). That the institutional and citizen component of democratic quality might be causally related, or in some way mutually dependent, does not prevent them from forming part of the same higher-order concept of democratic quality. Although it is rarely explicitly recognized (Collier and Adcock, 1999: 559), existing quality-ofdemocracy indices already include indicators that are causally related or mutually dependent: for example, the degree of civil liberties and the competitiveness of electoral institutions. In a booklength study on the theory and practice of concept formation, Gary Goertz (2006: 60-62) describes this type of 'within-concept' component interdependence as the 'conjunction of noncausal necessary conditions.' Our argument is that the concept of democratic quality comprises this very sort of within-concept component interdependence between the institutional and citizen components of democratic quality, whereby the value of one is contingent (more or less) on the value of the other.

The paper proceeds as follows. We begin with a discussion of existing comparative qualityof-democracy indices. This section shows how scholars have focused on institutions and structures while paying limited attention to citizens who bring these institutions and structures to 
life. The next section examines three key models of democracy. We show here how each of these models identifies not only specific institutions and structures as conceptually constitutive of democracy but also specific citizen dispositions. We then present an analytic framework, rooted in research from political psychology and political behavior, to help guide a theory-driven selection of indicators related to citizens' democratic commitments, political capacities, and political participation. The paper ends with a brief discussion of some important implications of our argument for future quality-of-democracy research.

\section{Existing research and the neglect of citizens}

Existing quality-of-democracy indices conceptualize democratic quality primarily in terms of the structure of opportunities that allow citizens to exercise self-government. As such, they focus on a range of institutions including rights and rules, both from a de jure and de facto perspective. Most indices are to varying degrees conceptually rooted in Robert Dahl's minimalist understanding of democracy as consisting of two components: namely, participation and contestation. Typically the participation component is operationalized in terms of the procedural rights that undergird and determine the selection of political representatives and whether elections are free from corruption and abuse (Marshall et al., 2011). As for the concept of contestation, this is generally operationalized in terms of the rules that guide electoral competition as well as observed levels of competition between parties and candidates (e.g., Alvarez et al., 1996; Przeworksi et al., 2000; Vanhanen, 2000).

Several quality-of-democracy indices go beyond these minimalist indicators. Freedom House, one of the most frequently used sources for evaluating democratic quality, publishes an annual index that includes wide-ranging measures of civil liberties (see also Munck, 2007). In recent 
years, research on democratic quality has also increasingly included a broader array of institutional indicators. The goal of this new research has been to operationally accommodate the institutional variegation that characterizes real-world democracy. One of the most notable recent examples of this line of inquiry is the Varieties of Democracy (V-Dem) project (Coppedge at al., 2012). A large-scale, international collaborative undertaking, V-Dem has greatly improved our understanding of democratic quality thanks to its incorporation of indicators related to a host of institutions and structures.

In contrast to its innovative selection of institutional and structural indicators, the V-Dem project departs little from existing research when it comes to the inclusion of indicators related to citizen dispositions. It specifically identifies 'attitudes and political cultures' as not being constitutive of democracy, based on the argument (Coppedge et al., 2012: 8, italics in original) that V-Dem 'does not attempt to incorporate the causes of democracy (except insofar as some elements of [the] far-flung concept [of democracy] might affect other elements).'

Although some indices exclude citizens altogether (Alvarez et al., 1996), many incorporate citizens by way of a measure related to national electoral turnout rates (e.g., Vanhanen, 2000). In doing so, researchers acknowledge that gauging democratic quality requires information not just about institutional opportunities but also about citizens themselves. In the past decade comparative work has begun to take this idea of the inclusion of citizens more seriously. Larry Diamond and Leonardo Morlino (2004: 23) write, for instance, that 'democratic quality is high when we in fact observe extensive citizen participation [...] in the life of political parties and civil society organizations, in the discussion of public policy issues, $[\ldots]$ and in direct engagement with public issues at the local level.' 
Two indices that include a broad set of measures related to citizens are worth noting. The first is the 'Index of Democracy' published annually since 2010 by the Economist Intelligence Unit (EIU 2015); the second is the 'Democracy Barometer' created by a team of researchers in Germany and Switzerland. In terms of the role played by theory in selecting citizen-related indicators, the EIU and Democracy Barometer are poles apart. On the one hand, the EIU provides no information on the criteria used to select citizen-related indicators. Instead, the creators of this index present a cursory, broad-brush justification for the inclusion of citizens, arguing (2015: 36-37) that democracy is 'more than the sum of its institutions' and that a 'democratic political culture is also crucial.' On the other hand, the Democracy Barometer explicitly anchors its selection of citizen-related indicators in the democratic principles of freedom, equality, and control (Bühlmann et al., 2012). That being said, the conceptualization process underpinning the Democracy Barometer generates a set of ontologically singular understandings of these three principles.

As this brief review shows, within the well-established and growing field of quality-ofdemocracy research, one set of index developers more or less ignores citizens, while another includes them, though with little justification or with insufficient attention given to the ontological varieties of democracy. As a result, the conceptualization of the citizen component of democratic quality is severely underdeveloped in existing research.

\section{Citizens in key models of democracy}

A core component of our argument is that the selection of citizen-related indicators should be explicitly anchored in and driven by theory. The V-Dem project, described above, offers an excellent example of such a theory-driven approach. The creators of V-Dem deliberately cast 
their net wide based on the argument that there is no single conceptualization of democracy. They identify instead seven models of democracy, five of which form the backbone of their data collection efforts. These are the electoral, liberal, participatory, deliberative, and egalitarian models of democracy. In order to present and illustrate our argument, we retain V-Dem's theoretically diverse framework, focusing in particular on their first four models. The goal here is to show how these different models place demands on citizens as much as they do on institutions and structures; and just as the nature of these institutional demands vary across models, so does the nature of the demands placed on citizens.

\section{Minimal-elitism}

The electoral or minimal-elitist model of democracy is an aggregative one centered on free and fair, periodic elections dominated by elites and competition between political parties. Rule by elites, chosen by citizens as part of a competitive party-dominated bidding process, is defended as a guard against the ever-present threat of citizens' flimsy commitment to democracy being overcome by the greater appeal of mob rule. Though minimal-elitists circumscribe citizen action to periodic vote casting, they still identify a range of characteristics and dispositions that citizens are supposed to possess for democracy to function properly. Given the centrality of elected party elites, minimal-elitists believe citizens should willingly retire from political life between elections and desist from 'political back-seat driving' (Schumpeter, 1950: 295). In addition, minimal-elitist democrats expect citizens to possess certain skills and resources. To illustrate these skills and resources, E. E. Schattschneider (1975: 134) draws a direct comparison between politics and consumer choice, noting that 'it is not necessary to know how to make a television set in order to buy one intelligently.' When it comes to the moment of having to choose one 
party or politician over another, citizens must therefore be able to 'judge things by their results' and 'take advantage of what other people know.'

\section{Liberal-pluralism}

Liberal-pluralism holds that democracy is realized through checks and balances ensuring that elected politicians and institutions are constrained by other institutions and the actions of other elites, including the judiciary and subnational tiers of elected government. Politically engaged citizens provide a further important check and balance to the power of parties and elected politicians. As John Stuart Mill (2009 [1861]: 9) writes, 'representative institutions are of little value, and may be a mere instrument of tyranny or intrigue, when the generality of electors are not sufficiently interested.'

In recent years, liberal political theorists have become increasingly interested in 'citizenly virtues' as conceptually constitutive of democracy. As Stephen Macedo (1996: 240) notes, 'the health of the liberal public order depends on our ability to constitute not only political institutions and limits on power, but appropriate patterns of social life and citizen character.' Chief among the citizen virtues identified by liberal-pluralists is self-interest. Dahl's concept of 'enlightened understanding' (1989: 112), which he identifies as one of five core requirements for democracy, represents an important articulation of the place of the self-interested citizen within liberal-pluralism.

\section{Participatory and deliberative democracy}

Except in their most radical forms, participatory and deliberative accounts of democracy recognize the importance of elections as well as the role played by political parties and elected 
politicians in the democratic process. Advocates of participatory and deliberative democracy are opposed to the idea of public decision making being driven exclusively or predominantly by a market-like logic of competitive aggregation. Instead, public decision making should rest on dialogue, reciprocity, and reflection. Though differences exist between participatory and deliberative democracy in terms of the cognitive and expressive skills required of citizens, the two models of democracy share a common broad account of citizens as politically active and open to mutual understanding. As Benjamin Barber (1984: 154) remarks, participatory democracy 'is not government by 'the people' or government by 'the masses' [...] 'Masses make noise, citizens deliberate; masses behave, citizens act; masses collide and intersect, citizens engage, share, and contribute.'

\section{Which citizen dispositions?}

While all key models of democracy identify citizens as conceptually constitutive of democratic quality, it is equally clear from the above discussion that they place different demands on citizens. As a result, a 'one-size-fits-all-approach' would be inappropriate when incorporating citizens into quality-of-democracy indices. That being said, regardless of the model(s) of democracy driving the evaluative exercise, we propose that scholars pay particular attention to three broad categories of citizen-related indicators. We do so based on scholarship from political behavior and political psychology, in which three classes of citizen dispositions stand out as focal points of research. These include democratic commitments, political capacities, and political participation. Building on the previous section, we now turn to a discussion of how different models of democracy call for each of these three dispositions to be measured in different ways. (For a schematic summary of this discussion, see Table 1.) Our aim here is not to 
operationalize each disposition but rather to provide a parsimonious operational framework for the systematic inclusion of citizens in future quality-of-democracy research.

\section{Democratic commitment}

Democratic commitment operates at two levels. The first is at a high level of abstraction, manifested by a general preference for democracy over non-democratic forms of political organization. The second is at a more specific level, evidenced by a commitment to particular democratic principles, values, and norms. The minimal-elitist citizen is expected to be committed to electoral democracy as the ideal instantiation of popular rule. Living in this type of democracy she also believes that electors should willingly retire from political life between elections. Related to this political acquiescence, she is committed to compliance with all laws and to the principle of political tolerance that facilitates the proper functioning of a marketplace of ideas.

Liberal-pluralists envision citizens with a more expansive set of democratic commitments. While supportive of electoral democracy and the key legislative role played by political parties and elected politicians, the liberal-pluralist citizen also sets great store by influence beyond the ballot box. She is committed to the ideal that citizens are able to mold the political agenda through collective action and shape the form and content of public policy on a continuous basis, valuing the democratic import of a vibrant public sphere populated by politically independent organizations and associations. Ultimately, however, she views elected politicians as responsible and accountable for the final decisions made within this system of pressure politics. Finally, though embracing conflict and competition between values and ideas as fundamental features of a well-functioning democracy, the liberal-pluralist citizen also recognizes tolerance, negotiation, 
bargaining, and compromise between organized and elite groups with opposing viewpoints as important democratic principles.

For most exponents of participatory and deliberative democracy the democratic citizen supports the key structures, institutions, and actors of electoral democracy. In addition, she is committed to a democracy with both the right and the opportunities to make citizen voices heard between elections individually as well as through collective action, prizing various forms of citizen participation, be they direct or dialogue-oriented as well as mediated and unmediated.

\section{Political capacity}

Political capacity generally takes two forms in existing empirical research. The first is capacity as something intrinsically political due to its proximate relation to politics: that is to say, capacity involving identifiably political resources that citizens possess and can draw upon to engage with democratic institutions and actors. The second form of political capacity is latently political in the sense that it includes cognitive, organizational, and expressive skills honed in non-political spaces that can be transferred to the political arena.

The minimal-elitist citizen need only possess fairly modest political capacities to carry out the single political act of choosing between political alternatives in intermittent elections without being duped. This requires a modicum of interest in politics at the time of elections and the competence to select from a pre-established menu of political options using heuristics and cues to make appropriate electoral choices.

In contrast, the liberal-pluralist citizen is interested in politics during as well as between elections. She is capable of identifying her political preferences and defending her interests, mainly by relying on intermediary organizations. Accordingly, for liberal-pluralists citizens 
should possess the necessary cognitive and communicative resources to engage in interest groups as a means of political voice and influence.

The participatory-deliberative citizen possesses many of the same capacities as those demanded by liberal-pluralists, including engagement in interest groups, but has a greater capacity to cooperate and deliberate with others who have different preferences and interests, be they political, economic, or social. The participatory-deliberative citizen also has the capacities, cognitive and communicative, to justify her preferences and have them transformed by listening to others.

\section{Political participation}

That some form of citizen participation is constitutive of democracy is a fundamental tenet of all theories of democracy as well as many strands of comparative empirical research. In an early pioneer study on political participation, Sidney Verba and Norman Nie (1972: 1) go so far as to state that 'Where few take part in decisions there is little democracy; the more participation there is in decisions, the more democracy there is.' The voluminous body of empirical research that exists on political behavior identifies three broad categories of political participation. The first category includes activities directly related to the electoral process, most notably voting but also campaigning for a political candidate or party. The second comprises activity that is related to

politics beyond the ballot box, for example, attending town-hall meetings or taking part in a demonstration. The third category encompasses activities that are political in a latent or extragovernmental or 'pre-political' sense and have the potential to be used for political purposes.

What forms and levels of political participation should be considered when conceptualizing democratic quality depends on the model driving the evaluative exercise. For scholars of 
minimal-elitism the primary and even sole act of mass political participation is the casting of one's vote in periodic elections. In liberal-pluralism, voting remains a fundamentally important act of political participation, but intermittent participation between elections, mainly indirectly through intermediary groups, is important too. Scholars of participatory and deliberative democracy have a more expansive conceptualization of public participation. In addition to voting, the participatory-deliberative citizen participates in the democratic life of her community on a continuous basis in a variety of ways, involving collaboration and interaction between and among citizens and public officials centered on high-quality communication and deliberation.

INSERT TABLE 1.

\section{Conclusion}

Despite welcome developments in recent years that have broadened the conceptual basis of democratic quality, citizen dispositions continue to play second fiddle to institutions, both conceptually and empirically. This paper offers a corrective to this, providing a new foundation for future cross-national empirical work. We have argued that the concept of democratic quality consists of two necessary, interdependent components: the quality of a country's structural and institutional opportunities for democratic rule on the one hand; and the dispositions of citizens who breathe life into these opportunities on the other.

In addition to making the case for a full and systematic inclusion of citizens, we provided a parsimonious analytic framework to help guide the selection of citizen-related indicators. Drawing on work from political behavior and political psychology, from which quality-ofdemocracy research has to date been largely disconnected, we propose that scholars pay 
particular attention to three key categories of citizen dispositions: namely, democratic commitment, political capacity, and political participation.

Including citizen dispositions in future quality-of-democracy research can be achieved by drawing on a variety of data sources. Responses from single-country and cross-national surveys such as the European Social Survey or regional barometers, provide a wide range of data related to democratic commitments, capacities, and different types of political participation. In addition, primary and secondary materials from official sources and international organizations offer useful information related to political participation, including rates of voter turnout and membership of political parties and other relevant organizations. These same sources also provide other behavioral indicators (such as tax compliance, criminality, and electoral support for extremist parties) that could be used in different ways to capture levels of mass democratic commitments, including law-abidingness and tolerance. Country experts working in a variety of substantive areas offer a third important source of information for gauging citizen dispositions. Scholars of social movements, community activism, and participatory processes could, for example, be valuable sources of information for the levels and types of political capacity available in a given society.

When drawing on this rich stock of data to incorporate citizens into future cross-national assessments of democratic quality, two important implications of our argument are worth highlighting. First, our institutions-in-reality understanding of democracy requires a judicious use of multiplicative as well as more traditional additive aggregation processes. At the core of this paper lies the idea that the overall level of democratic quality in a country can only be considered high when there is a tight fit between democratic institutions and the dispositions of citizens to breathe life into these institutions. What counts as a fit will crucially depend on the 
underpinning model/s of democracy. The key point however is that this notion of fit is based on the idea that institutions and citizens stand in a mutually conditioning relationship, and as such, in operational terms, the value of one is related more or less to the value of the other. Future work that aims to incorporate citizens into the measurement of democratic quality will therefore need to be explicit about when and why scores of institution-related and citizen-related indicators are added together, or indeed when the scores of certain institutional and citizen-related indicators are dependent on each other in some way, reflected by the use of a multiplicative term.

Second, future research must be explicit about the model or models of democracy driving the evaluative exercise. Until recently, quality-of-democracy research has been largely silent on this issue, but as the V-Dem project shows there is a growing recognition that assessments can and should be anchored in multiple ontologies. Taking seriously this idea of democratic variegation is especially important when it comes to including citizens. As we showed in the preceding pages, different models of democracy call for different types of commitments, capacities, and participation; and as such, they demand different types of citizen-related indicators. Scholars of democratic quality must aim to achieve theoretical consistency between institutional and structural indicators on the one hand and citizen-related indicators on the other. By selecting mutually consistent citizen and institutional indicators, clearly anchored in one or more model of democracy, future research will be in a better position to capture substantively meaningful variations in real-world democratic quality. 


\section{Notes}

1. These data come from Round 6 of the European Social Survey (2012), the 2009 European Election Survey, Waves 4 and 5 of the World Values Survey, and American National Election Studies.

\section{References}

Alvarez, Mike, José Antonio Cheibub, Fernando Limongi, and Adam Przeworski (1996) Classifying Political Regimes. Studies in Comparative International Development 31(2): $3-36$.

Barber, Benjamin (1984) Strong Democracy: Participatory Politics for a New Age, Berkeley; London: University of California Press.

Bermeo, Nancy (2003) Ordinary People in Extraordinary Times: The Citizenry and the Breakdown of Democracy, Princeton, NJ: Princeton University Press.

Bühlmann, Marc, Wolfgang Merkel, Lisa Müller, Heiko Giebler and Bernhard Wessels (2012) The Democracy Barometer, European Political Science 11(4): 519-536.

Collier, David and Robert Adcock, (1999) Democracy and Dichotomies: A Pragmatic Approach to Choices about Concepts. Annual Review of Political Science 2: 537-565.

Coppedge, Michael, John Gerring and Staffan Lindberg (2012) Global Standards, Local Knowledge: The Varieties of Democracy Version 1.0.Gothenburg: V-Dem Institute.

Dahl, Robert A (1971) Polyarchy. New Haven, London: Yale University Press.

Dahl, Robert A (1989) Democracy and its Critics. New Haven, London: Yale University Press. Dahl, Robert A (1992) The Problem of Civic Competence. Journal of Democracy 3(4): 45-59. 
Diamond, Larry and Leonardo Morlino (2004) The Quality of Democracy. An Overview. Journal of Democracy 15(4): 20-31.

Economist Intelligence Unit (EIU) (2015) Democracy Index 2014. Democracy and its Discontents. London: The Economist Intelligence Unit.

European Election Study (2009) EES 2009 Study. Cologne: European Elections Studies.

European Social Survey (2012) ESS Round 6: European Social Survey Round 6 Data (2012). Data file edition 2.0. Norwegian Social Science Data Services. Bergen: Norway - Data Archive and distributor of ESS data.

Freedom House (2014) Freedom in the World: The Annual Survey of Political Rights and Civil Liberties. New York: Freedom House.

Goertz, Gary (2006) Social Science Concepts: A User's Guide. Princeton, NJ: Princeton University Press.

Inglehart, Ronald, and Christian Welzel (2005) Modernization, Cultural Change, and Democracy: The Human Development Sequence. New York: Cambridge University Press.

Kymlicka, Will (2002) Contemporary Political Philosophy: An Introduction. Oxford, New York: Oxford University Press.

Macedo, Stephen (1996) Community, Diversity, and Civic Education, Social Philosophy and Policy 13(1): 240-268.

Marshall, Monty G, Keith Jaggers and Ted Robert Gurr (2012) Polity IV Project: Political Regime Characteristics and Transitions, 1800-2010. Data Users' Manual. Center for Systemic Peace.

Mill, John Stuart ( 2009 [1861]) Representative Government. Munich, Ravenburg: GRIN Verlag. 
Munck, Gerardo L (2007) The Study of Politics and Democracy: Touchstones of a Research Agenda. In Gerardo L. Munck (ed) Regimes and Democracy in Latin America: Theories and Methods. Oxford, New York: Oxford University Press, 25-37.

Przeworski, Adam, Michael E Alvarez, Jose Antonio Cheibub and Fernando Limongi (eds) (2000) Democracy and Development. New York: Cambridge University Press.

Rustow, Dankwart (1970) Transitions to Democracy: Toward a Dynamic Model. Comparative Politics, 2(3): 337-363.

Schattschneider, Elmer Eric (1975) The Semisovereign People, Hinsdale: Dryden.

Schumpeter, Joseph A (1950) Capitalism, Socialism and Democracy. New York: Harper Perennial.

Vanhanen, Tatu (2000) A New Dataset for Measuring Democracy, 1980-1998. Journal of Peace Research 31(2): 251-265.

Verba, Sidney, and Norman H. Nie, (1972) Participation in America: Political Democracy and Social Equality. New York: Harper \& Row. 
Table 1. Citizen dispositions according to key models of democracy

\begin{tabular}{|c|c|c|c|}
\hline & Minimal-Elitism & Liberal-Pluralism & Participatory-Deliberative \\
\hline $\begin{array}{l}\text { Democratic } \\
\text { commitments }\end{array}$ & $\begin{array}{l}\text { - Acceptance of elected } \\
\text { elites as sole decision } \\
\text { makers. } \\
\text { - Willingness to retire } \\
\text { from public life between } \\
\text { elections. } \\
\text { Commitment to comply } \\
\text { with law of the land. } \\
\text { - Politically tolerant. }\end{array}$ & $\begin{array}{l}\text { - Acceptance of elected elites } \\
\text { as primary decision makers. } \\
\text { Support for continuous } \\
\text { demand making by } \\
\text { organized interests. } \\
\text { Commitment to ideal of } \\
\text { democracy as requiring } \\
\text { competition, bargaining, and } \\
\text { compromise among } \\
\text { organized interests. } \\
\text { Politically tolerant. }\end{array}$ & $\begin{array}{l}\text { - Support for idea that elected elites } \\
\text { should involve ordinary citizens in } \\
\text { decision making both at and between } \\
\text { elections. } \\
\text { - Acceptance of principle that citizens } \\
\text { should have wide-ranging } \\
\text { opportunities to communicate and } \\
\text { deliberative with each other. } \\
\text { - Endorsement of idea that citizens have } \\
\text { - a duty to be politically engaged. } \\
\text { Politically tolerant. }\end{array}$ \\
\hline $\begin{array}{l}\text { Political } \\
\text { capacities }\end{array}$ & $\begin{array}{l}\text { Modicum of capacities } \\
\text { required to choose } \\
\text { candidate or party at } \\
\text { time of election. }\end{array}$ & $\begin{array}{l}\text { Moderate capacities to make } \\
\text { informed electoral decision } \\
\text { as well as undertake political } \\
\text { activities during election } \\
\text { period. } \\
\text { Cognitive and } \\
\text { communicative resources to } \\
\text { engage effectively with } \\
\text { interest groups between } \\
\text { elections. }\end{array}$ & 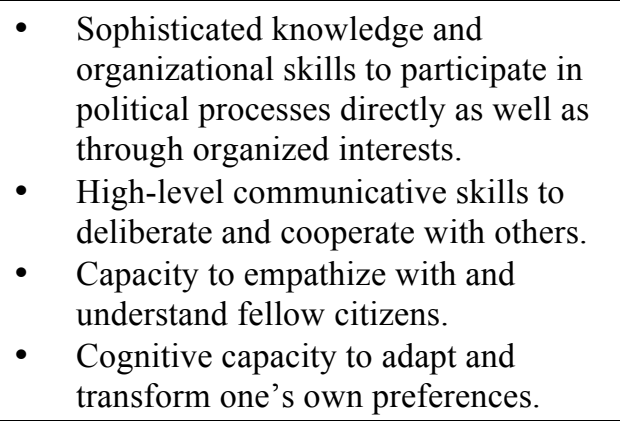 \\
\hline $\begin{array}{l}\text { Political } \\
\text { participation }\end{array}$ & $\begin{array}{l}\text { - Casting vote in periodic } \\
\text { elections. } \\
\text { - Passive consumption of } \\
\text { campaign information. }\end{array}$ & $\begin{array}{l}\text { - Active engagement in } \\
\text { electoral campaigns as well } \\
\text { as casting vote. } \\
\text { Engagement with interest } \\
\text { groups, including } \\
\text { intermittent interest-group } \\
\text { activism. }\end{array}$ & $\begin{array}{l}\text { - Continuous participation in political } \\
\text { life at and between elections. } \\
\text { Active involvement in electoral and } \\
\text { non-electoral processes that require } \\
\text { high-quality communication and } \\
\text { deliberation. }\end{array}$ \\
\hline
\end{tabular}

